\title{
ROMANIAN LANGUAGE AND LITERATURE: INTERCULTURAL EDUCATION IMPLICATIONS
}

\author{
VIORICA GORAS-POSTICA ${ }^{1}$ \\ ${ }^{1}$ Moldova State University, Faculty of Sciences of Education, Psychology, Sociology and Social Assis- \\ tance, Department of Science of Education, Mateevici 60 str., Chisinau, MD-2009, Moldova. ORCID \\ 0000-0001-9096-621X, Email: vpostica@prodidactica.md
}

ABSTRACT: The study approaches the new curriculum documents for pre-university education in the Republic of Moldova from the intercultural education perspective. In the 2019-2020 school year, the schools in the country are carrying out the education process based on a new curriculum, which represents the result of the third reform after the country's independence in 1992. The author analyses the correspondence of the curriculum texts to the stipulations of the Education Code, and the extent to which they respond to the demands in the development of the students' intercultural competence. The findings of the study reveal that the texts are focused not only on the promotion of the national values and identity, but are open, at the same time, to the intercultural education and to the dialogue with representatives of different cultures in the multicultural divided society. Literature and policy review supplemented by discourse analysis are the main qualitative methods applied.

KEYWORDS: Curriculum text, Romanian language and literature, school subject, intercultural education, intercultural competence, students, teachers

\section{INTRODUCTION}

During the last three years in the Republic of Moldova there has been an extensive process of curricular development reform, involving several educational actors: students, parents, teachers, managers, researchers, decision-makers and activists in the associative sector. The ministries of two ministers of education and several development partners were involved, carrying out logical stages of public consultation, university 
and pre-university teachers cooperated in working teams to produce qualitative regulatory documents. Despite many difficulties and misunderstandings, we believe that it was an important democratic exercise and that the third curricular reform in the country, after the proclamation of independence, is a higher quality stage and the curricula, presented and analyzed in our study, will demonstrate this. The most important issue is that the new developed documents should contribute in a significant way to the achievement of the educational ideal, declared in the Educational Code (EC) - "the formation of personality with initiative spirit, capable of self-development, possessing not only a system of knowledge and skills necessary for employment in the labor market, but also independence of opinion and action, being open for intercultural dialogue in the context of assumed national and universal values" (EC 2014, art. 6). Apparently, the intercultural perspective of the Romanian language and literature in the national school curriculum may seem paradoxical. The primary goal of our paper is to answer some public discourses spread in our society regarding the ethnocentric character of the school documents and the educational process. According to the Reference Framework of the National Curriculum (RFNC 2017), the development of the National Curriculum cannot be effective without taking into account the challenges of the contemporary world: globalization, internationalization, digitalization, technology, value crisis; national context, marked by social-political, economic and demographic crisis; the state of the current curriculum: the high degree of theorization of the curricula by disciplines, the low level of achievement of the interdisciplinary approach within the curricular framework, the lack of consensus in approaching the notion of "competencies", the synchronization between the formative/current and the final evaluation, etc. Therefore, the need for curricular changes was determined by adjusting curricular policies to the national and international educational standards; by ensuring continuity in curricular reforms and educational policies, the functionality of curricular cycles in relation to the trends of curricular development at national and international levels; by adjusting the curricular framework in relation to the dysfunctions identified in its piloting and monitoring processes. (RFNC 2017: 3) Based on this, from the point of view of the role and importance of the curricular system, the RFNC stipulates the curricular products, materialized in three categories of curricular documents:

- conceptual/policy documents: national curriculum reference framework; the educational framework plan and educational standards;

- projective documents: study plans for pre-school, primary, secondary, high school; curriculum for disciplines (programs); long-term and short-term teaching projects;

- methodological documents: school textbooks; methodological guides; multimedia sets; educational software; assessment tools/ tests (RFNC 2017: 8).

From the list above we will analyze one general regulatory act - RFNC and three specific ones concerning the key subject in the school plan - the Romanian language and literature (RLL), as integrative discipline. Starting from the general situation pre- 
sented by us, we consider that it is important to carry out a theoretical exercise, with explicit practical aims, for the critical analysis of the given documents, from the intercultural perspective. It can contribute to the increase in the quality of implementation of the projective documents, as well as to the initiation of a new public debate and scientific research in the field. In the EC and in RFNC the key competencies needed to be achieved by the students, that are integrated into the compulsory education process are the same as the ones stipulated in the European framework of competencies:

- Communication skills in the Romanian language;

- Communication skills in the mother tongue (for minorities students)

- Communication skills in foreign languages

- Skills in mathematics, science and technology

- Digital skills

- The competence of learning to learn

- Social and civic competencies

- Entrepreneurial skills and initiative

- Competence for cultural expression and awareness of cultural value (RFNC 2017: 17).

From the European Union perspectives and policies, the discourses of our educational documents, developed in the last 10-15 years, are politically correct, and they offer multiple opportunities for decision makers and for teachers, students and researchers in their activity, even though the social and political context does not support and contributes enough with his part to the common updated educational work. The intercultural education (ICE) issue is relevant for all educational documents because our context is multiethnic and multilingual. According to the 2014 census, ethnic minorities represent $17,93 \%$ of the population. The most numerous ethnic minority groups are Ukrainians (6.57\%), Gagauzians (4,57 \%), Russians (4,06 \%), Bulgarians (1,88\%); the native predominate (82,7 \%) (Recensamant 2014). The national minorities and a big part of Moldovan (more than $30 \%$ of the population) overwhelmingly use Russian as the main language of communication. This fact creates two largely separate linguistic spheres. Behind the linguistic division are two principal factors: first, an uncertain Moldovan national identity, which undermines the role of the state language, that as a result lacks its prestige and full acceptance as the unique official language of Moldova. As for the Russian language, the dominant language during the Soviet period, it enjoys a residual prestige, which however does not mean that its speakers do not feel menaced by the loss of their language official status in 1989. According to the statistical, but also to the historical and current facts, Moldova is a divided society, based not only on the multiethnic and multilingual structure of the population, but also because of the identity crisis of the inhabitants - a big part of them are not considered themselves as Moldovan citizens with different ethnical roots, but as Russians, Moldovans, Romanians etc. This is an important argument to 
educate the cultural and intercultural values through the all school subjects and the Romanian language and literature is one of them. The correct scientific name of our/ state language is Romanian and Academia of Science of the country, as the highest scientific authority, signed a special declaration on this issue, but the political name of the language, used starting with the Russian/soviet occupation of the country (1812, 1940), and used in the Constitution (art.13) is Moldovan. This fact is one of the causes of the interethnic conflicts in the society - a big part of the Russian speakers and some of the Moldovan citizens name the language Moldovan, but intellectuals people and a great majority of Romanian speakers named it the Romanian language, and they have fought to maintain and to promote the historic and scientific truth for more than 30 years, but the results are not yet visible at a large social scale. Despite the political debates and the daily life conflicts, the school must carry on its activity, promoting general human values and the historical and scientific truth, especially because in this respect, the article 6 of the Education Code of the Republic of Moldova stipulates the fundamental principles of education, such as: a) the right to education, without any distinction of race, color, sex, age, health status, language, religious belief, political or other type of opinions, nationality, social origin or ethnicity, material situation and property, etc.... and j) interculturality and a guarantee for ethnic and cultural identity (EC 2014).

In conclusion to the introductive part of our paper, we underline that the intercultural competence (ICC) is necessary to be formed through the all the dimensions of education, and also through the "new educations", which respond promptly to the needs of the contemporary world. The disciplinary / curricular levels on which the intercultural education is carried out, with the aim of the specific competency, are varied, including linguistic and literary education, civic education, religious education, moral education, etc. Based on the education of tolerance of cultural, ethnic, linguistic, social, denominational, etc., intercultural education is carried out throughout the compulsory school level, continuing, in a varied and contextual way, throughout the entire lifetime.

\section{A THEORETICAL FRAMEWORK}

The school curriculum has a dual significance in the Moldovan education system. In a broad sense, the curriculum designates all the educational processes and learning experiences that the student goes through during their school career. In a narrow sense, the curriculum includes all the regulatory documents of the school, in which the essential data regarding the educational processes and the learning experiences that the school offers to the student are recorded. This set of documents is called a formal or official curriculum; at the same time our scholars use "curriculum" thus replacing the well-known "program of study". In the last 30 years, in the European context, especially in our geographic zone a lot of books and articles were written on this topic, a lot of doctoral dissertations were defended, and numerous public debates took place, at different levels (Crisan et al. 2006; Potolea and Manolescu 2006; Neagu and Achiri 2008; Marin 2012; Pogolsa 2013; Singer et al. 2014; Bocos, Jucan 2017). The curricu- 
lum paradigm focuses on asserting the priority role to the purposes of education, at the level of any pedagogical project. The other elements of the curricular model of the training approach are structured depending on the purpose such as teaching-learning methods, assessment strategies and contents. In S. Cristea's (1998) vision "the emergence of the paradigm of the postmodern curriculum is due to the need to resolve conflicts between the psycho-centric and socio-centric approach to education, between education and training, between teacher and student" (p. 14).

Developed according to the provisions of the Education Code of the Republic of Moldova (2014), of the National Curriculum Framework (2017), of the Basic Curriculum: Competence System for General Education (2018) and of the Recommendations of the European Parliament and the Council of the European Union, on key competencies from the perspective of lifelong learning (Brussels 2018), the curriculum on the subject of the Romanian Language and Literature is a regulatory document, which provides the interconnection of conceptual, theleological, content and methodological approaches, the focus being placed on the system of competencies as a new frame of reference for educational ends. The National Curriculum in RLL is the foundation and the guideline of the teaching staff, it facilitates the creative approach to long-term and short-term didactical design and the actual achievement of the teaching-learningevaluation process. As the main subject in the study plan, presented/valorized in the school curriculum, RLL plays an important role in the development of pupils' personality, in the formation of lifelong learning skills, as well as in the integration into a knowledge-based society. The structure of a curriculum involves the following elements: preliminaries, curriculum conception, administration of the discipline by years of studies and number of hours, learning units, competencies(skills) versus competencies units, recommended contents, didactic strategies/learning activities, strategies for evaluation and bibliography. The administration of the discipline within the „Language and communication” curricular area, as acompulsory subject is presented in the table below acoording to the number of hours per week.

Table 1. Numerical and precentage proportion of RLL hours

\begin{tabular}{|c|c|c|c|}
\hline Grades & $\begin{array}{l}\text { Number of RLL hours } \\
\text { per week }\end{array}$ & $\begin{array}{l}\text { Total nr of hours per } \\
\text { week }\end{array}$ & $\begin{array}{l}\text { Total number of hours of } \\
\text { RLL in the school year }\end{array}$ \\
\hline Ist grade & $8(36,3 \%)$ & 22 & 231 \\
\hline $\begin{array}{l}\text { II-IV gra- } \\
\text { des }\end{array}$ & $7(31,81 \%-30,43)$ & $22 / 22 / 23$ & 264 \\
\hline $\begin{array}{l}\text { V-VI gra- } \\
\text { des }\end{array}$ & $6(23,07 \%-22,22 \%)$ & $26 / 27$ & 204 \\
\hline $\begin{array}{l}\text { VII-IX } \\
\text { grades }\end{array}$ & $5(16,66 \%-17,24 \%)$ & $30 / 30 / 29$ & 170 \\
\hline $\begin{array}{l}\text { X-XII gra- } \\
\text { des }\end{array}$ & $\begin{array}{c}5 \text { (Humanistic profile) } \\
\text { and } 4 \text { (realistic profile) - } \\
(18,52-14,28 \%)\end{array}$ & $27 / 28$ & $156 / 136$ \\
\hline
\end{tabular}

Source: own elaboration based on RFNC and of RLL curricula texts 
Thus, a subject represented by such a big number of hours, spent by students and teachers in the classroom, should be able to develop all cross/transversal competencies, mentioned above, because the communication in the Romanian language and the competence for cultural expression and the awareness of cultural value and literary skills remain the main outcomes in the whole process. The intercultural competenceis is to be perceived as a part of the last one. In this respect, as it was stipulated in the recent normative acts, the students must actively face the multiethnic and multicultural character of the Moldovan society, in order to report in a constructive and positive manner this diversity; to show respect for their own and the others' rights, regardless of their ethnicity, language, culture, religion, gender, age or social status; to respect the social and cultural beliefs of others, rejecting any kind of intolerance, extremism and racism; to demonstrate responsibility for oneself and the others, for the society and the environment; to actively and responsibly exercise their own rights, while respecting the rights of others; to value the diversity; demonstrate tolerance and an inclusive attitude; to practice and promote human values in daily life (respect for personal dignity; fighting against prejudice and discrimination of any kind, against poverty and marginalization; promoting gender equality, etc.). In the specific objective no. 9 - The development of international relations and the promotion of intercultural policies in education - from the Education Strategy (ES) - 2020 the following strategic orientations are provided:

(i) the connection to the European educational values and standards;

(ii) the promotion of advanced international standards and experience in the field of multilingual and multicultural education;

(iii) the creation of partnership mechanisms with the respective structures at an international level;

(iv) the promotion of intercultural education at all levels of the educational system;

(v) the creation of the legal framework regarding the implementation of international reforms in the educational field;

(vi) the sociolinguistic integration of the students studying in educational institutions with training in Russian, by expanding the number of school subjects in the Romanian language. (ES 2014)

Our research is focused on respecting by the political discourse of the main policy documents of the Article 29 of Children's right Convention, which stipulate (c) "the development of respect for the child's parents, his or her own cultural identity, language and values, for the national values of the country in which the child is living, the country from which he or she may originate, and for civilizations different from his or her own;(d) the preparation of the child for responsible life in a free society, in the spirit of understanding, peace, tolerance, equality of sexes, and friendship among all peoples, ethnic, national and religious groups and persons of indigenous origin”. In the direct sens, the childrens rights, upon the political and educational discourses are 
respected, but in the indirect one, there are a lot of problems which negativelly affect the children and we analyse them in our paper.

The multicultural society, in which different people coexist, needs the promotion of constructive interactions, intercultural education and the maintenance of a balanced intercultural dialogue in the school curriculum. Upon Romanian professor, "performing intercultural education implies that the educational process itself is carried out in an interactional environment, by putting together, face to face, the bearers of different cultural expressions" (Cucos 2000: 7). Synthetically, intercultural education aims at a pedagogical approach to cultural differences, a strategy that takes into account spiritual or gender specificities (gender differences, social or economic difference, and others), avoiding, as far as possible, the risks resulting from the unequal exchanges between cultures or, even worse, the tendency of atomization of cultures. The intercultural approach, shown in a paper edited by the Council of Europe, is neither a new science, nor a new discipline, but a new methodology that seeks to integrate, in the interrogation on the educational space, the data of psychology, anthropology, social sciences, politics, culture, history (cf. Perotti 1992: 191). Thus, we can say that intercultural education is an important topic of the educational discourse, that extracts its raw material from the perspectives opened by the disciplinary links.

The term intercultural is perceived as stressing the process of interaction competencies. "There is a tendency in Europe to see multicultural as a less dynamic concept and as describing a situation which has a diversity of cultures while intercultural is used to indicate the interaction of and relationship between different cultural groups in a culturally diverse setting" (Gunilla and Zilliacus 2009).

Moldovan professor Vl. Paslaru (2003) found that the identity crisis and the property crisis are two sequels of the past that the national school is about to root out, in order to educate new generations of citizens aware of this (p. 39). These adversely affect the openness to intercultural dialogue of many generations of citizens from our country, but also from other areas occupied/colonized during recent history. In this sense, the school is going to assume multiple cultural roles, and such tasks can often exceed the teachers trained in the past, with an inherited mentality from the old regime.

In the postmodern context, intercultural competence is imposed as a necessity and an actuality for the citizen of each country, from Europe or from other parts of the world, as the process of globalization is expanding. Conscious, to a greater or lesser extent, of this phenomenon, our children are to be carefully guided in order to acquire vast and functional knowledge about national and universal culture, in the broadest sense of the word. They try multiple learning experiences for skills acquisition and, at the same time, should be helped to form correct skills, to manifest openness and availability to communicate and interact in a civilized way with anyone on the planet, including the person who is nearby, to cooperate with them in order to solve common problems. All current curriculum documents must underline the intercultural education perspective, with its inherent advantages and problems. In this respect, teachers from all stages of schooling need continuous training in the field, awareness and appropriate guidance. Registered in the area of civic competencies, as well as personal and interpersonal competencies, intercultural competence includes all forms of be- 
havior that allow each person to participate effectively in the social and professional life, being directly linked to the individual and collective well-being. These competencies are related to the democratic citizenship, the use of the knowledge, skills, values and attitudes necessary to promote inclusion, justice and sustainable development, while respecting all human rights and fundamental freedoms.

Intercultural education is directly connected with education through and for values /axiological which passes as a red thread through the curriculum in all school disciplines, and also through the curriculum of RLL, Moral-spiritual education, Religion, History and Education for society. In this sense, the Religion Curriculum mainly promotes Christian values, which are the defining ones for any human being, manifested by faith, hope, love, identity, family, education, friendship, preferences, relations between people, but also other general human values: life, truth, holiness, good, beauty, love, patience, purpose, willingness, dignity, uprightness, cleanliness, forgiveness, mercy, oriented towards moral-religious perfection. According to the curricular provisions, the implementation of these values will contribute to establishing a coherence between the content of education and the socio-cultural environment; knowledge / promotion of the cultural heritage of the people; formation and development of appropriate social integration and adaptation behaviors; formation and development of a positive, autonomous attitude that harmonizes the relationship with oneself and others, with the environment (RFNC, p. 3-4). In the same sense, Const. Cucos (2000) states that "the school must be cultural first, then intercultural" (p.5), and the cultural basis on which intercultural dialogue takes place is welcomed, in the relevant book, where the problem of intercultural education starts from the description of the axiological implications.

As a reference work on the given topic, in the Romanian area, but fully connected to the recent international approaches, we mention the research of the Nedelcu (2007) dedicated to the specific interrelated topics such as diversity, minorities, intercultural competence, intercultural curriculum, pedagogy of diversity with "the triple opening to practitioners (teachers, for whom there are concrete suggestions, practical ideas, content analysis, etc.), decision makers, responsible for the elaboration of specific educational policies (for example, suggestions for curricular construction, development of training programs for teachers, etc.), field theorists and students of the faculty profile" (p. 3). The practical issues of the mentioned research, with multiple practical functions, reveal our school realities, on the one hand, sensitive to maintaining the national identity of the growing generation, and on the other hand, aware of the immanence of cultivating the openness to the diverse and constantly changing intercultural social relations.

\section{METHODOLOGY}

The integrated literature and policy reviews supplemented by discourse analysis are the main qualitative methods applied in this paper. Document analysis indicators are developed based on the mission of education, as declared in the Code of Education, which consists of the measure/level through which the national curricula guides/con- 
tributes to the promotion of intercultural dialogue, tolerance, non-discrimination and social inclusion. The underlined words will serve as key terms for the text analysis as a specialized discourse, supplemented by other affiliated words, as differences, diversity, cultural values, identity, conflict resolution, problems solving, democratic, participation, community, society. These selected words define the ideology/philosophy of the texts from the perspective of the intercultural education, which is essential for determining the ideology /orientation of the curriculum reform. It is important to deduce if the thematic issues direct the educational actors to the development of intercultural competencies at each school level. The main reason for the research is to analyze how the key concepts contribute to the description and to the enlargement of the other concept - identity/ national identity, culture (national and universal) because of the Romanian language, as a basic trait of the titular nation. All translations in the paper were done by the author. The research question for our study is if the texts of the main curricula documents are ethnocentric/ focused only on the promotion of the national values and identity, or are open, at the same time, to the intercultural education and to the dialogue with representatives of different cultures in our multicultural divided society and how they contribute to the development of students' intercultural competence.

\section{QUALITATIVE RESEARCH ISSUES AND FINDINGS}

So, in the main curriculum document - RFNC - key term for our research- intercultural - is used 4 times: in the citation of the educational ideal from the Educational Code, in the innovative table with the generic attributes of the school graduates, as a characteristic of the people who are civically engaged and responsible (p.27), as a feature of young citizens of the Republic of Moldova, who have to demonstrate, at the end of the high education process, the "interest and involvement in intercultural dialogue" (p.29) and as one of the modern principles of quality assurance of textbooks and teaching materials - "socialization, through the development of social skills and the promotion of intercultural education" (p.55).

From the same lexical family, the term tolerance is used among the characteristics of the high education graduate, who "knows and appreciates their own cultural identity; shows understanding, respect and tolerance for cultural, ethnic and confessional diversity; is involved in activities to promote the national cultural identity, in relation to the European cultural identity and the cultural diversity of the world" (p.32).

The social inclusion term is used in a definition of the competencies, as a "transferable and multifunctional package of knowledge, skills, abilities, values and attitudes that allow the individual to achieve their professional fulfillment and development, social inclusion and professional insertion in the respective field" - (p.15) and as a condition of a successful educational process, related to respecting "the principles of individualization, differentiation, personalization in the learning process, efficiently ensuring the inclusion process (p. 62).

The terms conflict and conflict resolution are used as an element of the transversal competencies, among characteristics of people who can work in a team, who "can pos- 
itively resolve conflicts that arise through their recognition and work on them together with dialogue partners", and among the characteristics of the responsible citizens, who can "use conflict resolutions strategies" (p.20). In a society in which students grow up seeing and feeling many interpersonal, social and ethno-linguistic conflicts, these skills should be developed and extended in various contexts, through all the school disciplines.

Other affiliated terms in the analyzed documents are differences and diversity which are frequently used, and we consider it relevant to point out the context of introducing them on the curriculum framework agenda: in the chapter with the presentation of the transversal competencies for the educational system in Moldova, among the responsibilities implied by team work there is one referring to "the appreciation of the diversity of ideas, the respect of ethnics and cultural differences and their use as resources in group processes" (p.20), for primary school graduates as main characteristic are to" know the main popular traditions and customs of the Republic of Moldova in their cultural diversity and participate in activities dedicated to them"(p.32) and, in the same context, the characteristics for secondary school graduates are: "they know and appreciate the cultural and spiritual treasure of the Republic of Moldova in its diversity and participate in initiatives to protect the national historical, cultural and spiritual heritage."(p.32) It is important also to mention that diversity is an indicator for evaluating the content of learning, from the scientific, cultural and social perspective (p.37), for methodology of the lessons (p.49), and for textbook designs (p.55).

The relevant context of the other term - respect - is concerned to the same characteristics of the school graduates who should" participate in activities that promote the public good, identify community needs and act to meet them; engage in activities to improve social life; demonstrate global responsibility, understanding and appreciation for different cultures" (p.26)

We did not find the term intercultural competence in the text of RFNC, it is clear that it is included in the key competence for cultural expression and awareness of cultural value, but, nevertheless, we consider that it is better to offer more explicitly, especially since in the previous curricular reform there was a great emphasis on this and innovative teaching materials were developed and disseminated in our school, including with the support of development partners in international resonance projects (Goras-Postica 2015, Gutu 2007, Cadrul de referinta 2015).

Other terms, which create the favorable pedagogic framework for the intercultural competence development, at conceptual and operational levels in the regulatory document - RFNC (in parentheses their frequency is given), are: social/society (45), culture/cultural (29) problem solving (35), participation (15), free/freedom (14), open/openness (14), community (9), rights (9), responsibility (8), civic (6), democratic (4), identity (3). All these connotations are evident in the context of a national curriculum focused on the student (92) and its needs, on the competencies (247) and on the values (51), which supports the intercultural approach of the whole educational process.

As the intermediary conclusion related to this regulatory act, we can underline the importance of creating a multicultural community/school with a well conceptualized intercultural perspective. The RFNC text is not ethnocentric or focused only on the 
promotion of the national values and identity. It is open to the intercultural education and contributes at conceptual and operational levels to the development of students' intercultural competence. The liberal discourse of the text helps us to be optimistic in relation to the applying aspects, even we have a lot of the cases in our past and current practice when on paper, in the policy documents, things are very good, but in practice, in quotidian school life, they are not well enough understood, promoted and applied. It is crucial to initiate more public dialogues on this topic, to materialize it in the curricula for disciplines and in the textbooks and in other learning materials. Also, this subject should be obligatorily included in the programs for pre-service and in-service teacher trainings, in order the intercultural perspective to become an element of each school culture and of each community life. As a synthesis, we present the following figure:

Figure 1. The cloud of terms on ICE perspective in RFNC

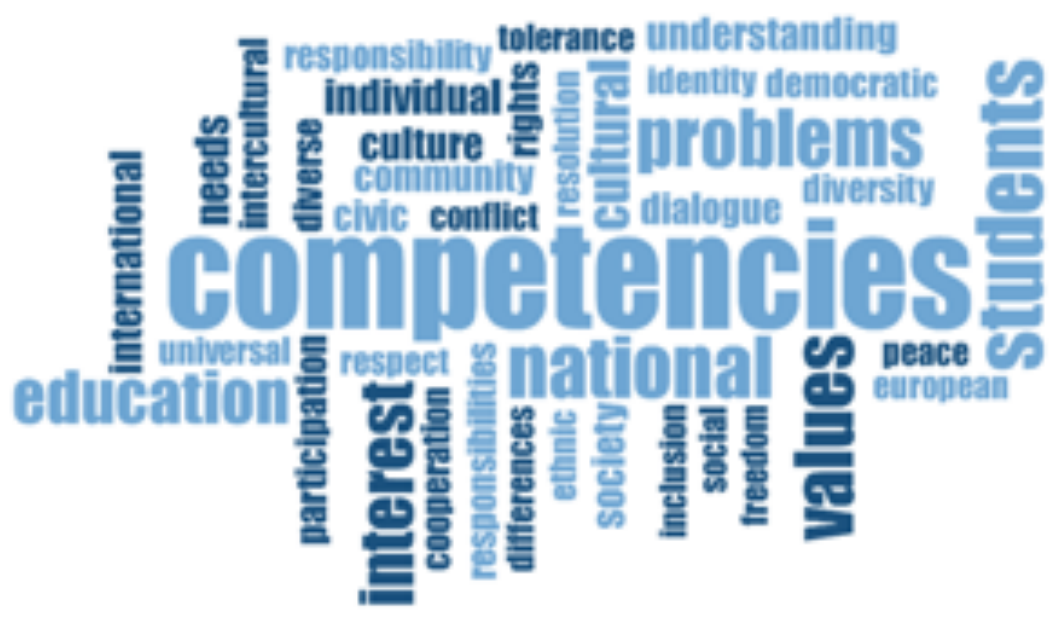

Source: own elaboration based on MAXQDA

In the Curriculum of RLL for primary classes, intercultural education is presented as a topic for transdisciplinary educational activities, which include didactic excursions, thematic trips, field, documentation and study visits, with the subject for each grade, as follows: Children's games and toys around the world; From the mysteries of museums; Tell me who you are, tell me what you love; Tourist expedition: Together through our Moldova. Also, tolerance as a predominant specific attitude is expected to be demonstrated during the discussion of the reading texts in each class, among other positive attitudes and values - attention and tolerance towards dialogue partners in different communication situations (p.25). Social inclusion in the primary classes is requested to be assured through the school inclusion of the children. At the chapter of the curriculum - recommended literary texts and books from children's literature - there are a lot of books by national classical writers and from universal literature, there are more from Russian literature, but none by the Ukrainian, Bulgarian or Gagauz writers, or by other minority cohabitants in our country. It is necessary for other ethnicity children learning Romanian language in national schools to find themselves in the messages of 
the taught texts. That is why is advised that the thematic list, as part of school documentation, is carefully selected. Many causes could be evoked: in school libraries and on the book market, in general, we do not have recent and well-translated editions of these writers, and also, publishers do not include them in editorial plans, because they are not requested by schools and readers. This situation, however, creates premises for the ethnic minorities to consider themselves neglected and marginalized, a thing which should be taken into account by the authors of textbooks and of the other educational materials, by the teachers and by the whole school communities, in order to cover the existing gaps.

Among six specific competencies of the integrated discipline RLL in secondary school classes/gymnasium, the first is: perceiving personal linguistic and cultural identity in a national context, showing curiosity and tolerance (p.6) The principles for selection of literary texts for study and reading offer openings especially for the achievement of educational values, citizenship education, education for democracy, personal and social education, global education, development education, education for environment / ecology, education for peace and tolerance, education for all and for everyone, education for media etc. (Apud Paslaru 2013: 35). From those analyzed by us, it seems that this document is less open to the intercultural education, because the key terms for the qualitative analysis cannot be found, but, indirectly, teachers and students can be guided by the specific competence stated above and they can act to develop the intercultural competence too.

The first specific competencies of the integrated discipline RLL for high school classes/lyceum is formulated as the expression of their own linguistic and cultural identity in a European and global context, demonstrating empathy and openness for linguistic and cultural diversity (p.14) In the conceptual framework chapter intercultural communication is given as a factor which contributes to the development of the whole scholar curriculum (p.3). Another important aspect in the same documents is referred to the units of the content for XII grade (p.26-27), which it concretizes on a horizontal basis the intercultural didactic approach and operationally presents the curricular elements that the teacher applies directly to the class. 
Table 2. Example of ICE in projected curriculum for high school

\begin{tabular}{|c|c|c|}
\hline Competencies units & Content units & $\begin{array}{l}\text { Recommended learning } \\
\text { activities and products }\end{array}$ \\
\hline $\begin{array}{l}\text { 1.1. Arguing the } \\
\text { concepts of plurilingualism } \\
\text { and interculturality } \\
\text { 1.2. Expressing } \\
\text { their own linguistic and } \\
\text { cultural identity }\end{array}$ & $\begin{array}{l}\text { - Linguistic and cultural } \\
\text { identity } \\
\text { - Plurilingualism and } \\
\text { interculturality } \\
\text { - Dialogue of cultural } \\
\text { values } \\
\text { - National consciousness } \\
\text { in the formation of modern } \\
\text { personality through the val- } \\
\text { ues of Romanian language } \\
\text { and literature } \\
\text { Transdisciplinary topics: } \\
\text { - } \quad \text { The Romanian lan- } \\
\text { guage - part of the European } \\
\text { linguistic heritage } \\
\text { - The linguistic behavior } \\
\text { of the generations of speakers } \\
\text { of the Romanian language: } \\
\text { common values and differenc- } \\
\text { es }\end{array}$ & $\begin{array}{l}\text { Activities: } \\
\text { Terminological and contex- } \\
\text { tual elucidations of the con- } \\
\text { cepts of plurilingualism, inter- } \\
\text { culturality. } \\
\text { Creation of blogs promoting } \\
\text { the natives by highlighting the } \\
\text { linguistic, literary and folklor- } \\
\text { ic specificities and influences } \\
\text { from the surrounding geo- } \\
\text { graphical areas. } \\
\text { Debates on the specificity } \\
\text { of national culture and other } \\
\text { cultures. } \\
\text { Publication in the media } \\
\text { (school, local, national) of prod- } \\
\text { ucts that reflect the attitude of } \\
\text { the cult speaker in relation to } \\
\text { their own linguistic and cultural } \\
\text { identity (optional) } \\
\text { Products: } \\
\text { Case study: Tolerance and } \\
\text { plurilingualism, thematic syn- } \\
\text { thesis. }\end{array}$ \\
\hline
\end{tabular}

Source: own elaboration based on RLL curriculum for XII grade

The terms conflict, conflict resolution, education for peace used 2-3 times in all 4 documents, we think it would be important for our context to include and to promote them more. They are used more frequently in the curriculum texts of History, Personal development and Education for society, and the texts from the textbooks and other learning materials should be taken into account this perspective. The most used terms in the all analyzed texts are value/values and students, so the current curriculum reform is one centered on the values and on the individual and social needs of our children, as future citizens of the Republic of Moldova and of Europe. In order to be more convinced, we offer some statistic data: 
Table 3. Frequency of the key term Value in the curricula texts

\begin{tabular}{|l|c|c|}
\hline \multicolumn{1}{|c|}{ Name of the document } & $\begin{array}{c}\text { Frequency of the } \\
\text { term Value }\end{array}$ & $\begin{array}{r}\text { Total number of the } \\
\text { pages in the document }\end{array}$ \\
\hline RFNC & 51 & 74 \\
\hline Curriculum of RLL (elementary school) & 36 & 35 \\
\hline Curriculum of RLL (Gymnasium) & 75 & 51 \\
\hline Curriculum of RLL (Lyceum) & 65 & 44 \\
\hline
\end{tabular}

Source: own elaboration based on curricula texts

In this context, we can conclude, that it is relevant and easy to interpret this issue, which successfully complete the intercultural perspective, because one of the function of the national curriculum, upon the RFNC, is the value function, for guiding the educational actions (p.10) and because of the three-dimensional structure of the competence centered curriculum: knowledge (to know), abilities (to know how to do); attitudes and values (to know how to be and how to interact with others) - (p.15). As a rule, transversal competencies derive from the key competencies, expanding and developing them. In this sense there are several models of taxonomies. From the intercultural perspective one of these is as follows: Works with a variety of individuals and groups: enhances the similarities and differences of the members of a group; separates the individual from his/her place/ role in the group; respects ethnic and cultural differences and uses them as resources in group processes; shows compassion towards others. Responds adequately with regard to complex interrelations: achieves a balance between personal and group needs; builds consensus; recognizes and uses the role of group dynamics; resolves positively the conflicts that arise by recognizing them and working on them together with the dialogue partners working in a group. And other transversal competence is related to the responsible citizenship, which must assume the following roles: demonstrate individual responsibility: recognize their own talents and competencies and use them for personal and social purposes; demonstrates integrity and dignity; uses conflict resolution strategies; raises awareness of how individual choices / decisions affect their own person, family and wider community; manifests initiative to inform and to act on problems and events of social interests; (...) understands and promotes the democratic principles of freedom, justice and equality: is aware of the fact that every human being has an innate value; demonstrates respect for human dignity, human needs and rights; promotes order and legality at the social level; respects and defends the rights and property; participates in democratic processes. d) participates in activities that promote the public good: understands the economic, political, social systems and ecosystems; identifies the needs of the community and acts to meet them; engages in activities to improve the social life; demonstrates global responsibility, understanding and appreciation for different cultures. (RFNC 2017: 21)

Moreover, other opportunities for educating the intercultural competence are offered by the optional/elective courses recommended by MoE for different curricular areas, especially for Language and communications and Social sciences areas. In each school year students have the opportunity to opt for the elective subjects (1-2 per 
classes), which are the flexible component of the educational framework plan, that contributes to the development of the cross/transversal competencies and priority areas, for example: civism, education for health and quality of life, entrepreneurship, creativity and innovation, education for sustainable development and intercultural education. The specific skills referring to the last one "understanding and recognizing the values of representatives of different cultures; collaboration, in the spirit of mutual respect, with other people from different environment, from an ethnic, cultural, religious or life-study point of view (learn to live with others)" (Plan-cadru 2018: 10-11). In this respect, we would like to mention the big contribution of the educational NGO, which developed a large area of optional subject, especially through the support of the international projects (http://prodidactica.md/en/optional-curricula/), even though it was not so easy to include them in the official list, now we have a very good situation, from the point of view of the written curricula. We hope, that the social impact will be more visible in the next years. The picture of these possibilities is represented in the table 3 .

Table 4. List of the optional subjects which promote ICE in Moldovan schools

\begin{tabular}{|c|c|c|}
\hline Elementary school & Gymnasium & Lyceum \\
\hline $\begin{array}{l}\text { - Culture of good neigh- } \\
\text { borhood } \\
\text { - Intercultural education } \\
\text { - Media education } \\
\text { - One hour for reading } \\
\text { (with a vast diversity of the } \\
\text { texts for reading and discuss- } \\
\text { ing) } \\
\text { - Religion } \\
\text { - Education for human } \\
\text { rights }\end{array}$ & $\begin{array}{ll}- & \text { Intercultural education } \\
- & \text { Education for tolerance } \\
- & \text { Religion } \\
- & \text { Education for human } \\
\text { rights } \\
-\quad \text { Media education } \\
-\quad \text { Education for commu- } \\
\text { nity development } \\
-\quad \text { Gender education } \\
-\quad \text { Elements of French/ } \\
\text { Spanish cultures and civiliza- } \\
\text { tions } \\
\text { - } \quad \text { History and traditions } \\
\text { of American people } \\
\text { - } \quad \text { Film education: a world } \\
\text { to be seen } \\
\text { - } \quad \text { Local history and cul- } \\
\text { ture } \\
\text { - Holocaust: stories and } \\
\text { life lessons } \\
\text { - } \quad \text { By reading, I learn to be }\end{array}$ & $\begin{array}{l}\text { - Let us know each other } \\
\text { better - Intercultural Educa- } \\
\text { tion through the literature of } \\
\text { the main ethnicities of the Re- } \\
\text { public of Moldova (Ukrainian, } \\
\text { Russian, Gagauz and Bulgari- } \\
\text { ans) } \\
\text { - By reading, I learn to be } \\
\text { - } \quad \text { Religion } \\
\text { - Elements of French/ } \\
\text { Spanish/German cultures and } \\
\text { civilizations } \\
\text { - History and traditions } \\
\text { of American people } \\
\text { - Film education: a world } \\
\text { to be seen } \\
\text { - Education for European } \\
\text { Integration } \\
\text { - Holocaust: stories and } \\
\text { life lessons } \\
\text { - Gender education }\end{array}$ \\
\hline
\end{tabular}

Source: own elaboration based on the Framework Plan for 2019-2020 school year 


\section{DISCUSSION}

As we can easily observe, the situation in the policy documents looks good, decision makers and authors/experts benefited in the last 30 years from a lot of the international training programs and have a good expertise in the field, but in reality there are a lot of problems with regard to the teacher professional development in order to ensure the good teaching of the issued topics and subjects. There are some main causes: almost half of the school teachers in the country are retired or very close to the retirement age and few of them are open to learning new and innovative approaches to the problem of intercultural education; the large fluctuation of teacher population (many teachers trained in projects give up the pedagogical activity and leave to work abroad). For young people trained in universities, the pedagogic profession is not attractive - modest social status and low salaries. The didactic materials published in the projects are few, insufficient for all the schools, and the ministry of profile does not have the necessary means, and it has not taken any initiative to supplement the book publishing for the optional subjects. The vast majority of the teaching materials on the subject are in electronic form, available on the official website of the ministry or of the other profile institutions, but not all teachers have sufficient digital skills to use them, many schools and universities do not have the ICT equipment in the classrooms so that could be used at the lesson, during teaching, in order to become functional for the students. So, we insisted on these aspects, because from the point of view of social pedagogy, the social context plays "a fundamental role in the design and development of education, and this role is valid at two reference levels - at projected goals and at means of achievement. The position of the educated person, though not neglected, is subordinate to the social, as a component part of it" (Cristea 2010: 53). The ambiguous political discourse of the politicians, the obvious polarization of the opinions of the officials and the long-term economic crisis, which greatly affect the quality of education, do not seem to us to be of minimal importance. We speak here about the education carried out daily in the school, in the family, in the society, not only the one projected in documents, which must comply with international standards. Just one example of recent discourse from mass media can offer clarity on the discussed situation:” The change would take years, because in 28 years of independence everything was destroyed and demolished. We are trampled into a world where injustice and inequality have grown sharply. This explains why thousands and thousands of citizens are looking for a job abroad. The locals show a relative optimism regarding the future of their children's perspective. Few are those who put more value on what politicians say or write in documents or in the press." (EL 2019) So, even the though discourse of the political documents and of a lot of mass media channels is liberal, the contradictions are easily observed and this situation generates confusion for young generation and distrust in the educational message transmitted by school.

\section{CONCLUSIONS AND RECOMMENDATIONS}

The present study was aimed to explore the intercultural education perspective of the main official documents which guide the educational process of the Moldovan 
students in the pre-university/secondary education level. It copes with the misunderstandings of the multiethnic and multilingual context, influenced in the past by the communist and soviet ideology, and nowadays by Russian imperial propaganda. The results suggest a variety of conceptual terms used by legacy and curriculum authors to build a new/modernized reality adapted to the 21st century, and to introduce the values of the national and European identity and of the constructive interaction with others in order to enrich the horizon of knowledge, life skills, of tolerant and respectful attitudes towards all citizens, regardless of ethnicity, language, religion or social status. We have identified that all the analyzed terms characterize the liberal discourse of the curriculum reform, and they will help teachers, students and parents to be educated as citizens with national dignity, open to a constructive dialogue and to face the challenges of diversity as a key characteristic of nowadays Moldovan context. It is important to create more learning materials and to initiate more school activities aimed to develop intercultural and multilingual competencies, based on national values and on native language, that are rooted in the historic and scientific truth, free of politics and ideologies. Also, it would be desirable for the scientific research in the field to address at a qualitative pragmatic level the problem of intercultural education from the perspective of students, teachers, parents, but also of the immediate, and of the lasting impact, felt by the society. At the same time, other curricula should be analyzed from the EIC perspective, in order to ensure the balanced didactic discourse at all levels of education, offered by different school subjects and through the school culture as a holistic approach.

FUNDING: This research was funded by the UNESCO/Janusz Korczak Chair fellowship 2019 obtained through the Polish Commission for UNESCO.

CONFLICT OF INTEREST: The author declares no conflict of interest.

\section{REFERENCES}

Bocos, Musata. Jucan, Dana. 2017. Fundamentele pedagogiei. Teoria si metodologia u r riculumului. Bucuresti, Romania: Editura Paralela 45.

Cadrul de Referinta al Curriculumului National. 2017. Chisinau, Republic of Moldova. Retrieved September 6, 2019, from http://particip.gov.md/public/documente/137/ ro_3966_CadruldereferintaalCurriculumuluiNaional23022017.pdf).

Children's right Convention. 1989. Retrieved September 6, 2019 (https://www.ohchr. org/en/professionalinterest/pages/crc.aspx).

Codul Educatiei al Republicii Moldova. 2014. Chisinau, Republic of Moldova. Retrieved June 4, 2019 (https://usmf.md/wp-content/uploads/2013/08/Codul-Educatiei. pdf).

Curriclumul national pentru invatamantul primar. 2018, Chisinau, Republic of Moldova. Retrieved August 4, 2019 (https://mecc.gov.md/sites/default/files/curriculum primare_05.09.2018.pdf). 
Curriculumul national. Disciplina Limba si literatura romana. Clasele V-IX. 2019. Chisinau, Republic of Moldova. Retrieved August 23, 2019 (https://mecc.gov.md/sites/ default/files/limba_si_lit_romana_curriculum_sc_nat_gimnaziu.pdf).

Curriculumul national. Disciplina Limba si literatura romana. Clasele X-XII. 2019. Chisinau, Republic of Moldova. Retrieved September 3, 2019 (https://mecc.gov.md/ sites/default/files/limba_si_lit_romana_curriculum_sc_nat_liceu.pdf).

Crisan, Alexandru. (Editor) 2006. Current and Future Challenges in Curriculum Development: Policies, Practices and Networking for Change. Bucuresti, Romania: Education 2000+ Publishers. Humanitas Educational.

Cristea, Sorin. 1998. Dictionar de termeni pedagogici. Bucuresti, Romania: Editura Didactica si Pedagogica.

Cristea, Sorin. 2010. “Pedagogia sociala”, Didactica Pro 1(59): 53-56 Chisinau Republic of Moldova. Retrieved September 13, 2019 (https://ibn.idsi.md/sites/ d e f a u lt / files/imag_file/Pedagogia\%20sociala.pdf).

Cucos, Constantin. 2000. Educatia. Dimensiuni culturale si interculurale. Iasi, Romania: Polirom.

Educatie pentru o societate a cunoasterii: Cadrul de referinta al noului Curriculum National. 2015, Chisinau Republic of Moldova: Institutul de Politici Publice.

Goras-Postica, Viorica. 2015. "Competenta interculturala: functionalitate conceptual-practica.” Pp. 8-20 in Competenta interculturala. Auxiliar didactic. Chisinau, Republic of Moldova: CE PRO DIDACTICA.

Holm, Gunilla and Zilliacus Harriet. 2009 "Dialogues on Diversity and Global Education." Pp. 11-28 in Multicultural Education and Intercultural Education: Is There a Difference?, edited by M. Talib, J. Loima, H. Paavola and S. Patrikainen. Berlin, Germany: Peter Lang. Retrieved September 11, 2019 (https://www. researchgate.net/publication/281555019_Multicultural_education_and_intercultura_education_Is_there_a_difference).

Gutu, Vladimir. (coord.) 2007. Cadrul de referinta al Curriculumului National. Chisinau, Republic of Moldova : A.I.E.P. Stiinta.

Gutu, Vladimir. 2014. Curriculum educational. Cercetare. Dezvoltare. Optimizare. Chisinau, Republic of Moldova: CEP USM.

Gutu, Vladimir. (coord.), 2015. Cadrul de referinta al Curriculumului Universitar. Chisinau, Republic of Moldova: CEP USM.

Marin, Tudor. 2012, Fundamentele pedagogiei. Teoria si metodologia curriculumului. Problematica educatiei contemporane. Bucuresti, Romania: Pro Universitaria.

Neagu, Mihaela. Achirii, Ion. 2008. Evaluarea curriculumului şcolar proiectat Ghid metodologic. Iaşi, Romania: Editura PIM.

Nedelcu, Anca. 2007. Fundamentele educatiei interculturale. Diversitate, minoritati, echitate. Iasi, Romania: Polirom.

Paslaru, Vadimir. 2003. Principiul pozitiv al educatiei. Studii si eseuri pedagogice. Chisinau, Republic of Moldova. Civitas.

Paslaru, Vadimir. 2013. Introducere in teoria educatiei literar-artistice. Bucuresti, Romania: Sigma.

Perroti, Antonio. 1992._Pour une politique d'immigration.“Pp. 199-202. Etudes. Tome 
377. Paris, France: S.E.R.

Planul-cadru pentru invatamantul primar, gimnazial si liceal pentru anul de studii 2019-2020. Chisinau, Republic of Moldova. Retrieved September 12, 2019 (https://mecc.gov.md/sites/default/files/plan-cadru_2019-2020_web_sait.pdf).

Pogolsa, Lilia. 2013. Teoria şi praxiologia managementului curriculumului. Chisinau, Republic of Moldova: Lyceum.

Potolea, Dan, Manolescu, Marin. 2006. Teoria si metodologia curiculumului. Bucuresti, Romania: Ministerul Educatiei si Cercetarii.

Recensamantul populatiei si al locuintelor in Republica Moldova. 2014. Chisinau. Republic of Moldova. Retrieved September 12, 2019 (http://recensamant.statistica. $\mathrm{md} / \mathrm{ro})$.

Schimbarea nu se face in 100 de zile... » Retrieved September 18, 2019 (https://moldova.europalibera.org/a/schimbarea-nu-se-face-in-100-de-zile-este-nevoie-deani-pentru-ca-28-de-ani-s-a-distrus-s-a-demolat-totul-/30163278.html).

Singer, Florence, Mihaela, Samihaian Florentina, Holbrook Jack, Crisan Alexandru. 2014. "A competence-based curriculum for the $21^{\text {st }}$ century. A case of Kuwait." Procedia - Social and Behavioral Sciences 128(22): 475-481. Retrieved September 23, 2019 (https://reader.elsevier.com/reader/sd/pii/S1877042814022824?token298BC9A01C60B0 B2637F5E6A2B9EDCEA719568CDC2887AC74B381FC9BF25CE41ED8A20A78F749 FE34649BC931AB1D6B6).

Strategia de dezvoltare a educatiei pentru anii 2014-2020 „Educatia-2020”. 2014. Chisinau. Republic of Moldova. Retrieved September 16, 2019 (https://mecc.gov.md/ sites/default/files/1_strategia_educatia-2020_3.pdf).

\section{BIOGRAPHICAL NOTE}

Viorica Postica, $\mathrm{PhD}$ is a professor at the Moldova State University, Faculty of Sciences of Education, interested in education, language, children's and women's rights.

OPEN ACCESS: This article is distributed under the terms of the Creative Commons Attribution Non-commercial License (CC BY-NC 4.0) which permits any non-commercial use, and reproduction in any medium, provided the original author(s) and source are credited.

ARTICLE HISTORY: Received 2019-09-30 / Accepted 2019-11-30 
